Int. J. Electrochem. Sci., 14 (2019) $886-896$

International Journal of

ELECTROCHEMICAL

SCIENCE

www.electrochemsci.org

Short Communication

\title{
Effects of Three Kinds of Hydrocarbon Degrading Bacteria on Biocorrosion Behavior of 16Mn Steel in the Bacteria-Containing Media
}

\author{
Xiaodong Zhao ${ }^{1, *}$, Kefeng Chen ${ }^{2,3}$, Jie Yang ${ }^{1 *}$, Guangfeng $X^{4}$, Haitao Tian ${ }^{1}$, Qingguo Chen ${ }^{2}$ \\ ${ }^{1}$ School of Ocean, Yantai University, Yantai 264005, China; \\ ${ }^{2}$ School of Naval Architecture and Mechanical-electrical Engineering, Zhejiang Ocean University, \\ Zhoushan 316022, China; \\ ${ }^{3}$ Key Laboratory of Marine Materials and Related Technologies, Ningbo Institute of Materials \\ Technology and Engineering, Chinese Academy of Sciences; \\ ${ }^{4}$ Shandong Special Equipment Inspection Institute Lute Inspection\&Testing Co. Ltd, Jinan 250100, \\ China \\ *E-mail: danielxdzhao@aliyun.com; kittyangj@163.com
}

doi: $10.20964 / 2019.01 .99$

Received: 16 October 2018 / Accepted: 14 November 2018 / Published: 30 November 2018

In this paper, the corrosion behavior of $16 \mathrm{Mn}$ steel in sterile medium and three hydrocarbon degrading bacteria containing environment was investigated by electrochemical impedance spectroscopy (EIS) and polarization curves. The results showed that self-corrosion current density of $16 \mathrm{Mn}$ steel in bacteriacontaining medium was significantly much less than that in sterile medium, suggesting the corrosion was inhibited by the attachment of the bacteria to the surface of the steel substrate. In the three bacteria-containing media, the difference of corrosion current densities resulted from the surface hydrophobicity of bacterial cells or ability to degrade organic matter.

Keywords: Microbiologically influenced corrosion (MIC), hydrocarbon degrading bacteria, Electrochemical impedance spectroscopy(EIS).

\section{$\underline{\text { FULL TEXT }}$}

(C) 2019 The Authors. Published by ESG (www.electrochemsci.org). This article is an open access article distributed under the terms and conditions of the Creative Commons Attribution license (http://creativecommons.org/licenses/by/4.0/). 